九州大学学術情報リポジトリ

Kyushu University Institutional Repository

\title{
Effluvia of the Foreign: Olfactory Experiences in Nagasaki during the Tokugawa Period
}

SHIMIZU, AKIRA

Wilkes University : Assistant Professor

https://doi.org/10.5109/2794932

出版情報: Journal of Asian Humanities at Kyushu University. 5, pp.113-123, 2020-03. Kyushu University, School of Letters, Graduate School of Humanities, Faculty of Humanities バージョン：

権利関係 : 


\title{
Effluvia of the Foreign: Olfactory Experiences in Nagasaki during the Tokugawa Period
}

\author{
AKIRA SHIMIZU \\ As I passed a place called Ichinose near Himi Pass, I detected a smell that I had never \\ experienced before. Feeling nauseous, I asked a member of my group what it was. I was \\ told that it was the smell of Nagasaki. \\ - Nagasaki miyage (A Souvenir from Nagasaki) ${ }^{1}$
}

\section{Introduction}

$\mathrm{N}$ 1679, a physician from Kyoto made his first journey to the port city of Nagasaki. He recorded his miscellaneous firsthand accounts of the city, its people, and its events, and in 1681 offered the collection of travel stories under the title Nagasaki miyage. ${ }^{2}$ During the Tokugawa period (1603-1867), Nagasaki was the only city where foreign traders such as the Dutch and Chinese were permitted to reside. Japanese visitors to the archipelago's only international city could "sense" foreign manners and customs that its denizens had appropriated into their everyday lives. The above epigraph is striking in that the author's olfactory sense obliquely perceived that foreignness. "The smell of Nagasaki" serves as a powerful vehicle for imagining how early modern Japanese travelers to Nagasaki, such as our unnamed doctor, differentiate Nagasaki from its counterparts.

Focusing on the city of Nagasaki, this essay explores the ways in which olfactory perceptions, especially those triggered by foreigners' consumption of meat,

1 Nagasaki miyage, pp. 6, 7. I would like to express my gratitude to Professor Arano Yasunori for directing my attention to this quote.

2 Ibid., p. 1. The author's record was later edited by an unknown Nagasaki resident and published in 1681 . were used by Japanese to identify the "other." Early modern Japanese deemed the physical contact with dead animals a cause of defilement, and perceived the practice of meat-eating as outside the cognitive boundary of Japan. While it has been proven that "mainstream" early modern Japanese secretly ate meat, this act was associated with non-mainstream or "marginalized" populations such as outcasts and foreigners, the latter of whom were only visible in Nagasaki.

During the Tokugawa period, Nagasaki was the only city where foreigners could reside, although they were restricted to the bakufu-designated compounds. In 1641 , the bakufu ordered the headquarters of the Dutch East India Company to move to the fan-shaped, manmade island of Dejima, while Chinese merchants were limited to the Chinese quarter, Töjin yashiki 唐人屋敷, in 1689. With some exceptions, the Dutch and Chinese were typically confined within these compounds until the end of the 1850s. As Dejima was connected to the mainland by only one guarded bridge, and the Chinese quarter was walled off, the mysterious lives of the foreigners inside sparked the popular curiosity of the Japanese. With the proliferation of the printing industry in the mid-Tokugawa period, many authors and painters responded by publishing works that described the foreign manners and customs practiced inside. 
Popular publications on Nagasaki gave opportunities to early modern Japanese to "see" foreignness in various visual expressions, prompting scholars including Ronald P. Toby, David Howell, and Suzanne G. O'Brien to study early modern Japanese "ocularcentrism" - sensory experiences that privilege vision. ${ }^{3}$ Their works demonstrate how outward physical expressions, both artistic and quotidian, such as hairstyles and facial hair as well as objects like frilly neckwear, hats, and parasols, allowed Japanese to draw cognitive boundaries that divided them from foreign "others." However, shifting our attention away from the visual to another sense, the olfactory (especially offensive odors) reveals another dimension of the cultural construction of foreignness. The historian Jonathan Reinarz challenges the prevalence of the "ocularcentric" hierarchy of senses that prioritizes vision and downplays smell in human perceptions. As he illustrates, the prominence of ocularcentrism in Western discourse has roots going back to the ancient Greeks such as Plato and Aristotle. However, "lesser" senses such as smell can also be used to observe culturally oriented human reaction among different groups of people. Further, the examination of olfactory experiences of the past allows us to explore the ways in which people historically configured and reconfigured themselves against their surroundings. ${ }^{4}$

Drawing on the work of the physician Linda M. Bartoshuk, the psychologist Rachel S. Herz has demonstrated that when encountering a new food, "[ $t]$ he conditioned aversion is to the smell, not the taste, of the substance."' A number of visitors to Nagasaki recorded their encounters with foreign dietary practices. They described experiences such as being served new foods by Nagasaki residents or even foreigners at their compounds and seeing (and smelling) the livestock likely used in these dishes. Their attention was commonly directed at meat, and it is rare to find visitors expressing their disgust based on the appearance of meat. As Herz writes, "[m] ost smells have a feel to them.." Based on a number of diaries kept by the travelers to Nagasaki, I demonstrate that the city's offensive smell had a psychological impact on these visitors that prompted them

\footnotetext{
3 See, for example, Toby, "'Ketōjin' no tōjō o megutte"; Toby, "Utamaro no ekizochikku to erochikku"; Howell, Geographies of Identity; O’Brien, "Splitting Hairs."

4 Reinarz, Past Scents, pp. 3-4.

5 Herz, "I Know What I Like," p. 198

6 ibid., p. 193
}

to associate it with the idea of foreignness. In particular, I argue that the smell of meat was the immediate trigger for Japanese visitors to categorize its consumption as outside "normative" Japanese practice, and the main factor that made the city of Nagasaki and its residents the embodiment of what could not be accepted according to "normative" standards of Japanese.

\section{Olfactory Experiences as a Useful Category of Analysis}

The primary method for the construction of "foreignness" has been deeply embedded in "ocularcentrism." As Ronald P. Toby has argued elsewhere, visual expression, especially in the form of hairstyle and facial hair, served as a medium through which "Japanese" identity was constructed vis-à-vis the existence of "others." tually, the Tokugawa bakufu attempted to normalize "Japanese" appearance through a series of edicts. For example, in August 1751, the bakufu issued an edict that men should not "arrange their hair in foreign ways" and saw such practice as having the potential to undermine "orderliness." Additionally, the 105-volume encyclopedia, The Pictorial Encyclopedia of the Universe of China and Japan (Wakan sansai zue 和漢三才図会, 1713) by Terajima Ryōan 寺島良安 (n.d.) includes entries on different hairstyles. Terajima declares that a style called sakayaki 月代—a hairstyle embodying what the historian David Howell calls "the three pillars of normative appearance of men" and featuring the topknot, shaved pates, and shaved faces - is the normative outlook for adult men. ${ }^{9}$

The early modern normalization of hairstyles (and facial hair) resulted in two sociocultural phenomena. First, those who did not conform to them were positioned outside the social order. A group of people referred to as kabuki-mono かぶき者 or roppō-mono 六 方者 who grew their hair and whiskers were considered as outlaws who threatened the political and social order. There were also groups of people such as monks,

\footnotetext{
7 Toby, "Ketōjin' no tōjō o megutte," p. 273. See also Toby, "The 'Indianness' of Iberia and Changing Japanese Iconographies of Other." Additionally, Timon Screech offers visual analyses on the popular gaze into the Chinese and Dutch who stayed at Nagasaki Inn (Nagasaki ya) in Edo. See Screech, The Lens within the Heart.

8 Takayanagi and Ishii, Ofuregaki Hōreki shūsei, p. 294

9 Howell, Geographies of Identity, p. 135
} 
physicians, intellectuals, and court nobles, who did not comply with "the three pillars," regardless of any privileges that they may have received. In short, their social existence was acknowledged outside the socalled "four-class system" with the samurai on the top followed by peasants, artisans, and merchants. Second, hairstyles and facial hair served as one of the visible parameters of "foreignness." A number of travel diaries offer accounts of encounters with foreigners-Koreans, Chinese, Dutch, Ryūkyūans (people from modern-day Okinawa; then the independent Ryūkyū Kingdom), and Ainu-by focusing on these physical features as the most visible symbols of difference. As we can see in the example of Terajima, visual symbols serve as a useful category of analysis when we think about how early modern Japanese configured themselves against foreigners. As Toby convincingly argues, the hair on one's head or face serves as an important visual semiotics because it is "the most conspicuous physical feature," and "its shape and color can be easily altered." ${ }^{\circ}$

Recent scholarship in history and anthropology has explored how nonvisual perceptions, such as smell, connect to issues of race and ethnicity. For example, the historian Mark Smith examines how race was constructed in the American Antebellum South. He writes that it is important for us to pay attention to an array of sensory experiences because they "help profile ordinarily hidden dimensions of racial thought and racism" and "tell us a good deal about the nature and workings of Antebellum Southern slavery." in which sensory experiences of both enslaved black people and white slaveholders contributed to the birth of racial stereotypes of two racial categories and maintains that "the senses facilitated the rule of feeling and made men and women unthinkingly comfortable with their racial worlds." ${ }^{\prime 2}$

The justification for Smith's heuristic approach had been presented by the historian Roy Porter, who famously quipped in his "Foreward" to Alain Corbin's seminal work The Foul and the Fragrant that "[T]oday's history comes deodorized." That is to say that modern

\footnotetext{
10 Toby, "'Ketōjin' no tōjōo megutte," p. 254.

11 Smith, How Race Is Made, p. 3. The number of publications deal ing with the senses in recent scholarship covering history and anthropology is vast. To name just a few, Corbin, The Foul and the Fragrant and Village Bells; Cohen and Johnson, Filth: Dirt, Disgust, and Modern Life; Barnes, The Great Stink of Paris; and Ashton, One Hot Summer.

12 Smith, How Race Is Made, p. 4.
}

hygiene has deodorized society, and restricted historians' sensitivity to past smells. Contemporary historiography, as a consequence, has been made visible and audible. ${ }^{13}$ However, if smell, more than vision and sound, induces such visceral and emotional reactions in its perceiver, this "lesser" sense will serve as a useful category of historical analysis. Smith identifies olfactory perception as the "hidden dimensions" of the process, especially when we think about the process through which one cognizes the existence of others.

The anthropologist Martin F. Manalansan IV has recently explored such dimensions in a contemporary social context, and directed our attention to the smell of food as a crucial niche to analyze ethnic identities. In his ethnographic study on Asian-American immigrant communities in New York City, Manalansan contends that "food odors become the medium through which identities are amplified or marked." ${ }^{14}$ In the multiethnic city of New York, the smell of food becomes the marker of ethnic differences and helps immigrants find "unthinkingly comfortable" spaces in which they can ensure their sense of ethnic belonging.

While Manalansan's ethnographic work underlines the power of food flavor as a trigger to reconfirm one's ethnic identity, historical materials seem to reveal that this mechanism is a result of one's bodily odor. According to Reinarz, western travelogues often highlighted "the absoluteness of social boundaries" that would divide "deodorized" white from "odorous" others. In this process, white travelers used a "perceived stench" to cognitively cordon off sensory realms and construct a civilized-uncivilized binary. ${ }^{15}$ Needless to say, such travelers' perceptions of what is negatively rendered as "stench" was merely the result of unfamiliarity. And, interestingly, the perception of the self as "deodorized" and the other as "odorous" implies the inherency of smell in human life and its surroundings. In this way, the West, as Porter implies, perceives itself as odorless and uses smell to construct its discourse of the civilized vs. uncivilized, where olfactory perception is directed only from the West to others.

However, a similar phenomenon existed in early modern Japan, where the natives odorized and otherized the Dutch and Chinese in comparison to their

\footnotetext{
13 Porter, "Forward," p. v.

14 Manalansan IV, "Immigrant Lives and the Politics of Olfaction," p. 46.

15 Reinarz, Past Scents, p. 86
} 
"odor-free" selves. It was especially the smell of foreign foods - namely meat - that triggered Japanese observers to draw this boundary. Mainstream early modern Japanese saw it as taboo to eat or even touch meat due to its potential to cause defilement. The discourse of meatless Japan, it should be noted, encouraged Japanese observers of foreign dietary practices to invent not a "deodorized-odorous" but an "odorless-odorous" binary, while perceiving the other as the embodiment of what they saw as the cause of defilement.

In his study on incense production in Japan, Brian Moeran explains how the Buddhist discourse employed smell to identify others. The Buddha's words are "fragrant," and the incense was "to invoke the Buddha's presence." On the other hand, it could be asserted that the smell of blood, or meat reeking of blood, would invoke the presence of demons (oni 鬼). ${ }^{16}$ Demons, usually depicted with facial hair, conjure up the image of "barbarians" (i.e., foreigners) that threaten Japan. In this manner, the incense's fragrance constitutes a stark contrast to the smell of flesh, and purifies the space in which the smell of flesh would cause "contamination" or "pollution" to "odorless" Japan.

\section{The Discourse of "Odorphobia" and Meat- Eating}

In the second half of the Tokugawa period, there was a growing number of publications concerning the "Japanese" diet. Many of them identified the five grainsrice, beans, barley, foxtail millet (awa 粟), and pearl millet (hie 稗) - as Japanese staple foods, the cultivation of and support for which was the crucial requirement for being Japanese. ${ }^{17}$ The Owari retainer Amano Sadakage 天野信景 (1663-1733) was one of the authors who wrote down such concerns. He authored a vast collection of miscellaneous essays entitled Shiojiri 塩尻 from the Genroku 元禄 years (1688-1704) up until his death. Although the collection does not seem to have

\footnotetext{
16 Moeran, "Making Scents of Smell," p. 440.

17 The historian Harada Nobuo offers a succinct overview of the history of grain eating in Japan, which culminated in the formation of the "five grain" (gokoku 五穀) discourse as defining what was "Japanese." See Harada, Edo no shoku seikatsu; Harada, Edo no ryôri shi; Harada, Rekishi no naka no kome to niku. Susan Hanley discusses a variety of grains consumed in early modern Japan as well as their regional diversity. See Hanley, Everyday Things in Premodern Japan, pp. 77-103.
}

been published, its writing style is largely similar to that of Japanese Neo-Confucian scholar Hayashi Razan 林 羅山 (1583-1657). Moreover, ideas expressed in Shiojiri influenced subsequent nativist scholars such as Hirata Atsutane 平田篤㡃 (1776-1843) and Motoori Norinaga 本居宣長 (1730-1801). ${ }^{18}$

According to Amano, the Japanese people did not eat meat because Shinto rituals had defined it as the cause of defilement, leading them to develop an aversion toward "the foul smell" of meat. Amano observed that people in Nagasaki, including Japanese people working on foreign ships, are "imbued with the foul smell of meat." However, he noted that "when the Dutch travel to Edo and if you get close to them, they do not smell so bad. For they do not eat meat for a certain duration of time after the departure from Nagasaki, so it disappears." ${ }^{19}$ That is, it was customs and not biological race that produced the offensive odors.

Despite Amano's statement to the contrary, a number of historical documents and archaeological findings have proven that early modern Japanese ate meat, including that of four-legged animals under the pretext of "medicinal eating" (kusurigui 薬食). ${ }^{20}$ In a block of the Kōjimachi 麦匊町 neighborhood of Edo, there was a section often referred to as "the beast market" (kemonodana 獣店) where people could walk into a restaurant called "the beast restaurant" (momonjiya ももんじ 屋) and eat, for example, the stewed meat of wild boar under the euphemism "mountain whale" (yamakujira 山鯨) for "medicinal eating." ${ }^{21}$ Under the guise of medical therapy, visitors to the beast market would feel exempted from being subject to defilement caused by their physical contact with meat. Additionally, we can confirm that miso-marinated beef was produced by the Hikone domain, and regularly presented to the shogun and high-ranking officials a total of twenty-eight times from at least 1781 onward. ${ }^{22}$

It is important for us to admit the possibility of a "gray" zone in regard to meat-eating, as it is quite unlikely that all Japanese shared the emotional impulses of disgust when they observed the practice of meat-eat-

\footnotetext{
18 Tanabe, "Shiojiri."

19 Amano, Shiojiri, vol. 17, p. 183.

20 For example, see Harada, Edo no shoku seikatsu; Uchiyama,

"San'ei-chō and Meat-Eating in Buddhist Edo"; Vaporis, "Digging

for Edo"; Cwiertka, Modern Japanese Cuisine; and Shimizu,

"Meat-Eating in the Kōjimachi District of Edo."

21 Shimizu, "Meat-Eating in the Kōjimachi District of Edo," p. 92.

22 Hikone-shi, Shinshū Hikone shishi, p. 266
} 
ing. Herz demonstrates that "our odor preferences are not innate and rather that we have learned through experience to like or dislike all the scents in our repertoire." ${ }^{23}$ In this sense, it is important that we investigate the specific cultural background in which each traveler developed his or her olfactory senses and by which he or she perceived the smell of meat negatively. However, this would require extensive research because the Japanese diet varied in accordance with geographical specificities. Those in the coastal areas consumed more fish than those in mountainous areas. Meanwhile, peasants in Kai Province (modern-day Yamanashi Prefecture) had more access to the meat of wild boars which they shot to protect their agricultural products. ${ }^{24}$

Despite the above regional differences, the discourse of defilement also created a narrative that associated meat with "foreign" and "marginal" characteristics in contrast to "normal" Japanese who abstained from meat. Amano wrote:

\section{In foreign countries, people conduct rituals in which they offer cows, goats, and pigs.... In our country, the offering of meat in the divine ritual is considered as the cause of defilement. This is because [the Japanese people] do not usually consume meat. How abominable blood-soaked meat is! $!^{25}$}

Here, we see the dual implications of the meat-eating discourse in Japan. On the one hand, the category of "our country" clearly contrasts with that of "foreign countries" in terms of the religious display of meat; on the other hand, the violation of the rule causes ordinary Japanese to be relegated to the status of outcast - a marginalized group of people whose defiled status the bakufu perpetuated and who were required to take "defiled" occupations involving dead animals. As Amano explains:

The reference of slaughterers as eta (穢多) originates in etori (えとり), which refers to feeding hunting dogs and falcons by killing animals. The reason that two Chinese characters, meaning "deeply defiled," came to be used is that they constantly strip off skin from various animals and gobble their meat, and, as a result, the smell of defilement diffuses from them. ${ }^{26}$

Here, the body of the outcast (eta) is viewed as the embodiment of "the smell of defilement" caused by their physical contact with dead animals. As a result, "our country" becomes a site that excludes the foreigners and outcasts because they embody the odors that "ordinary Japanese" do not emit. As a result, foreigners - especially Europeans - and "defiled" outcasts constituted a group of others. Finally, the potential to fall into this group of "others" through the practice of meat-eating threatened "ordinary" Japanese people, who were supposed to abhor those who emitted the smell of flesh. In other words, the religious discourse of not eating meat transforms into a discourse of "odorphobia" by which the category of the "ordinary" Japanese quarantines "others."

In his view of Buddhism, Amano outlines the discourse of "odorphobia" by suggesting that those who engage in the practice of meat-eating will be the target of demonic assault. For example, while contemplating "the purity of the water and flowers offered to the Buddha," Amano calls to mind the Buddhist rituals of Japan's neighboring countries, and finds it "deplorably unbearable" to see "meat reeking of the stench of fat" given as an offering. In order to avoid such practices, he calls for "the awareness of the urgency to have the will to endure a simple diet." Those who practice this simple diet appreciate "the purity of water and flowers" of Buddhist rituals, while those who make offerings of "meat reeking of the stench of fat" will be "devoured by the cursing demons attracted by its smell." ${ }^{27}$

According to Amano, Buddhist teachings reflected the Japanese sentiment that deemed the consumption of, and physical contact with, flesh to be a cause of defilement. While the fragrance of incense attracts various gods and goddesses, "the stench [of meat] will invite various demons and devils." If one fails to abstain from contact with meat, "demons, sensing its stench and seeking such failures, will curse one." ${ }^{28}$ The smell of meat is in defiance of the Buddha's teachings, and those who violate them will face the severe consequence of being cursed by demons.

\footnotetext{
23 Herz, "I Know What I Like," p. 190

24 Tsukamoto, Shōrui o meguru seiji. See also Harada, Edo no shoku seikatsu.

25 Amano, Shiojiri, vol. 15, p. 151
}

\footnotetext{
26 Ibid., vol. 14, p. 209

27 Ibid., vol. 15, p. 151

28 Ibid., p. 344 .
} 


\section{The Smell of Nagasaki from Afar}

Upon their arrival in Japan, the Europeans' practice of meat-eating quickly appeared as a threat to many "ordinary" Japanese, and its smell prompted them to draw cognitive boundaries between them and "odorous" others. As the Portuguese Jesuit missionary Luis Fróis (1532-1597) recorded, Japanese Buddhist monks often condemned Christianity as heretical for its consumption of meat, which supposedly included human flesh. In one instance recorded around 1590, a "suspicious" smell from a Christian man's oven provoked non-Christian Japanese to condemn him for cannibalism. In Yamaguchi, which was once the center of Jesuit missionary work, one blind Christian man was found in a house that Christian peasants maintained for their priest. After hearing about this man, thirty non-Christian women intruded into the house and mocked him. Sensing something from the oven in the kitchen, they derided him by saying: "It smells like human flesh has been grilled; the Christian must have eaten human flesh here." Then, a young man who accompanied these women picked up a bamboo stick which he used to try to find out what the blind man had cooked. Getting a whiff of the edge of the bamboo stick, he said: "It smells like human flesh." ${ }^{29}$ Here, the olfactory senses of non-Christian Japanese incited them to distance themselves from the Christians by attributing cannibalism to the foreign religion.

During the Tokugawa period, the ban on Christianity as well as the subsequent confinement of the Dutch and Chinese to Dejima and the Chinese quarter made foreigners all but invisible in Nagasaki and other parts of Japan. However, the smell of the foreign could not be controlled, and the daily manners and customs of the Europeans and Chinese filtered into the daily lives of Nagasaki residents. Coupled with the topographic characteristics of Himi Pass that divided the city and its surrounding areas, Nagasaki was narrated by many travelers as an isolated space surrounded by mountains and the ocean.

In the epigraph from Nagasaki miyage, "the smell of Nagasaki" obliquely sets a negative tone for the city. Here, it would be worthwhile to examine how Himi Pass contributed to the overall geographical characteristics of the city. Travelers to Nagasaki entered the

29 Fróis, Kuroda Kanbei, p. 261. city by land via a common route, of which Himi Pass served as the last difficult section. For example, the village head of Shindenshuku in modern-day Kanagawa Prefecture, Hatano Shinsaku 波多野新作 (n.d.), who accompanied his domain lord to Nagasaki, remarked in 1857 that "lengthy stone steps led up to Himi Pass, which is an extremely difficult spot [to pass through] ... we took a rest. The way down from the top of the pass is also a stone-paved steep." ${ }^{30}$ According to the bakufu official Tōyama Kagemichi 遠山景晋 (1752-1837), who traveled to Nagasaki in 1804, the steepness of the path and its width were not constant, which made passing more strenuous. ${ }^{31}$ In 1853, another bakufu official, Kubota Shigetsugu 窪田茂逐 (n.d.), described the path as very steep and rocky, while the edges of rocks on the path prevented him from proceeding smoothly. ${ }^{32}$

In 1802, a merchant from Owari domain (modern-day Aichi Prefecture) named Yoshida Shigefusa 吉 田重房 (n.d.) traveled to Nagasaki and attributed the climate of the city to its geographical characteristics. For him, Nagasaki was "humid, as it is surrounded by mountains on three sides and the ocean on one side." ${ }^{3}$ Here, Yoshida's observation indicates how the city and its residents were seen as isolated from their neighbors. This geographical characteristic alone seems to have prompted many travelers to inscribe the character of Nagasaki's townspeople as distinct from what they had witnessed in other parts of Japan. For example, the Okayama pharmacist Furukawa Koshōken 古川古松 軒 (1726-1807) recorded during his trip to Nagasaki in 1783 that the people in Nagasaki were "not empathetic at all," and those who had migrated from other areas "survived on stealing and were never ashamed" of such a way of life. ${ }^{34}$ Moreover, the Hiroshima domain retainer Hayashi Hideari 林英存 (n.d.) commented in 1804 that, despite the relative smoothness in his communication with the people of Nagasaki, he sometimes found their speech incomprehensible because their dialect had adopted Chinese sounds. ${ }^{35}$

In a similar way, "the smell of Nagasaki" was the outcome of the manners and customs of its residents.

\footnotetext{
30 Hatano, Nagasaki dōchūki, p. 58. Hatano was later promoted to Nagasaki Magistrate in November 1857.

31 Tōyama, Zoku mizouki, p. 214.

32 Kubota, Nagasaki nikki, p. 101

33 Yoshida, Tsukushi kikō, p. 666. Tsukushi kikō was published in 1806.

34 Furukawa, Saiyū zakki, p. 383.

35 Hayashi, Tsukushi no michikusa, p. 328
} 
According to the above travelers, Nagasaki residents seem to have developed their way of life with relatively less contact with the rest of Japan, and instead incorporated a greater degree of foreign elements in terms of their manners and customs. Amano heard this curious story from an anonymous Nagasaki resident:

Since the foreigners always practice meat-eating, their bodies smell. The stench of the Dutch can be detected even when their ships are one or two chō (町) offshore. This is because they rarely eat grains but only meat. When one passes by the Dutch on the street, one will cover his or her nose. ${ }^{36}$

Here, the foreignness of meat-eating-seemingly a distinct practice prevalent in Nagasaki-is contrasted with the Japanese diet which was centered on grains. By presenting this dietary juxtaposition, Amano constructs an "odorless" Japan in opposition to the "odorous” foreign.

Despite the reality of the early modern Japanese diet, the regular consumption of meat in Nagasaki led Amano, as well as the author of Nagasaki miyage, to describe Nagasaki as distinctively odorous. In the case of the Dutch, their smell was even perceptible from a distance at sea. That is, the odor of Nagasaki was not just local but also transmittable through the body of its residents imbued with it or by the wind. With these implications, Nagasaki itself seems to be an embodiment of the stench.

Japanese travelers perceived the foreignness of $\mathrm{Na}$ gasaki's dietary practices as foreboding even prior to their entrance to the city. In 1767 , Nagakubo Sekisui 長 久保赤水 (1717-1801), who was delegated to Nagasaki by the lord of the Mito domain, Tokugawa Harumori 徳川治保 (1751-1805), encountered free-range animals on the day of his entrance into the city. Having been received by officials dressed in formal attire, he "saw pigs and sheep prowling by the roadside." Puzzled, he asked one of the officials what they were for. The latter explained to him that "they were raised for Chinese people in Nagasaki who purchase and eat them." ${ }^{37}$ The aforementioned Yoshida Shigefusa perceived Nagasaki's distinct culture as he approached the Himi Pass.

\footnotetext{
36 Amano, Shiojiri, vol. 17, p. 183. One chō is about 109.09 meters, which is equal to 358 feet.

37 Nagakubo, Nagasaki kōeki nikki, p. 18.
}

The night before he entered Nagasaki, he described the food at a local inn as "foreign":

While I was waiting for the report from the express messenger (hikyaku 飛脚) whom I had sent to Nagasaki to secure lodging, I ordered sake and food. They served stewed eight-sun (寸)-long jack mackerel (aji 鯵) on a plate. In amusement, we laughed at the bizarreness of the dish by saying that since we were close to Nagasaki, the food appeared quite foreign. ${ }^{38}$

To his surprise, the jack mackerel that Yoshida saw was about 9.5 inches long. However, given that the fish averages between about 7.8 and 11.8 inches, Yoshida's meal was not particularly large. The amusement, as he notes, may have been caused by the way in which the fish was served, or because it was flavored in an unfamiliar way. Here, the reason for this amusement is unclear, but he undoubtedly identified the fish's appearance as "foreign." In any event, we see here that, along with Nagakubo's observation, food serves as a powerful marker to characterize Nagasaki.

The above travelers contrasted their experiences with what they conceived as the mainstream "Japanese" diet. Himi Pass and the surrounding mountains and ocean obscured the city, and "foreign" dietary practices were made invisible. However, while Nagasaki miyage suggests that "the smell of Nagasaki" spreads to the entrance of the city, the unfamiliar circumstances that they noted curiously served as the "pointer" to the foreignness that they would sense as they proceeded deeper into the city.

\section{The Nagasaki Olfactory Experience}

In Nagasaki, the dietary practices that accompanied the city's "foreign" elements attracted travelers' attention for not only their appearance and taste but also for smell. The practice of meat-eating attracted a lot of attention as Japanese people in theory did not consume meat. Many travelers "saw" animals raised by Japanese for sale to the Chinese and Dutch and described what they looked like; some of these witnesses, especially bakufu officials who had the privilege to travel to

38 Yoshida, Tsukushi kikō, p. 645. 
Dejima and gain entry into the Chinese quarter, actually ate meat dishes, and recorded the taste. Their impressions were not entirely negative. While some thought that the slaughtering of animals was an inhumane and malevolent act, others seem to have enjoyed the meat dishes and company of those who ate meat daily. However, their feelings about the smell of such dishes was another matter.

For the author of Nagasaki miyage who expressed the nausea he felt at the entrance to Nagasaki, body odor was an important aspect of etiquette. For him, a body reeking of a foul smell was a sign of vulgarity regarding one's place of birth. He stated that:

Among the Chinese, there are those who are noble and gentle by nature. They are always careful of their grooming and appearance, and concerned with their smell.... You will not find such people among the Dutch. Many of [the noble and gentle] Chinese are from Nanjing. [The reason that they have such etiquette] is that Nanjing was the capital of the august Ming dynasty. It is far more comfortable and pleasant to befriend [Chinese people with proper etiquette] than vulgar Japanese with bad breath... ${ }^{39}$

Here, one's "noble and gentle" nature is revealed in a pleasant odor emitting from one's body, while vulgarity is signified with bad breath. In other words, one's body is seen as the embodiment of one's quality, as manifested by body odor. The author's reference to "the capital of the august Ming dynasty" may indicate his inclination to, or respect for, Chinese culture and traditions, which downplayed the Dutch as so-called barbarians from the south. The nobility and gentleness were signs of the sophistication and "civilized" etiquette that would keep body odor pleasant, as opposed to the vulgarity signified by bad breath.

When Japanese travelers encountered meat dishes, their olfactory impressions were completely opposite. For example, in 1767 the aforementioned Nagakubo Sekisui was invited to Dejima. As he was received with different kinds of wines and confections, he tried them without hesitation and rather enjoyed them. Then, he was guided through the Dutch residence. As he walked into the kitchen, he witnessed the very moment when

39 Nagasaki miyage, p. 108 pigs and cows were slaughtered by having their heads smashed by hammers (togeki shite 屠撃して). This scene prompted him to comment, "I sensed the bloody stench caused by the slaughter of animals such as pigs and cows." 40

In 1781 , the physician Tachibana Nankei 橘南谿 (1753-1805) commented on the dietary practices of the people of Nagasaki. According to him:

Nagasaki is abundant in fish and meat more than any other place. Since they are less expensive than vegetables, people are sated with them. Also, while learning Chinese ways of cooking and drinking, they fry any kind of meat with thick flavors. In addition, as money flows in [from Chinese, Dutch, and Japanese from other areas], all of its people live lives of pleasure. Therefore, day and night, they indulge in eating and drinking without engaging in physical labor and activities. This is why many of them develop skin diseases. ${ }^{41}$

Here, the "thick flavor" of food is connected to the lack of "physical labor" and the possibility of "skin diseases." As Herz cautions us in her work on the development of olfactory preferences, flavor must be clearly distinguished from smell. While the former consists of "salt, sour, sweet, bitter and the latest addition umami or savory," the latter is the "combination of these basic tastes, plus smell." 42 For Tachibana, because of the adoption of Chinese foodways featuring deep-fried meat, "flavor" induces the degeneration of people in Nagasaki, especially since they do not have the means to burn off extra calories consumed in the form of "foreign" dietary practices. The ideal diet is, as Tachibana implies, a simple one practiced by people in Kyoto who pursue their occupations through physical labor. In other words, the dietary practice and physical activities must be in complete balance - the insufficiency of either one will undermine one's health, while an excess of thickly flavored food is also detrimental to one's health.

In August of 1853, the Russian Admiral Yevfimy Vasilyevich Putyatin arrived in Nagasaki onboard the Pallada along with three other frigates, and demanded

\footnotetext{
40 Nagakubo, Nagasaki kōeki nikki, p. 20.

41 Tachibana, Saiyūki, p. 315.

42 Herz, "I Know What I Like," p. 191. As she continues: "You distinguish the flavor of a cold cup of coffee from a glass of red wine only by smell."
} 
a commercial treaty with Japan. In response, the bakufu sent officials to negotiate. On the seventeenth day of the twelfth month, Putyatin invited a group of bakufu officials to Pallada and hosted a banquet. The bakufu's Financial Magistrate (kanjō bugyō 勘定奉行) Kawaji Toshiakira 川路聖謨 (1801-1868) and the abovementioned Kubota Shigetsugu were among them. According to Kawaji, bakufu officials were first served with aperitifs, beginning with French wine and ending with liquor, which reminded him of awamori 泡盛, today known as Okinawan rice brandy. Kawaji commented that the last liquor had a "pleasant aroma." Then, the banquet proceeded to dishes featuring different kinds of meat, vegetables, and fish:

When we were entertained by the Russians, there were dishes of beef, mutton, chicken, eggs, and vinegar-marinated vegetables. As I felt nauseous, I tried to eliminate their flavors with vinegar. ${ }^{43}$

Despite the similarity of Western drinks to awamori, the food represents a stark difference from what Kawaji would have been familiar with. Here, foreign "flavors" that come from the meat dishes function as the impulse for Kawaji's nausea.

The other official, Kubota, harbored a similar reaction towards the meat. Even before he was onboard, he sensed "a smell of cows which assailed my nose." As he explained, because of the Russians' "everyday practice of meat-eating, all of them give off a bad smell." 44 Implying that he was already familiar with the Russian dietary practices that incorporated beef, his olfactory impressions echo the story, submitting that the foreign body of the Russian was imbued with the smell of animal meat. That is, the foreign body was perceived as the embodiment of a bad smell. Then, after boarding the ship, he was guided to the basement where Kubota saw live animals:

At the center, there were cages in which birds and animals were kept. There were cows, sheep, buffalos (yagyū 野牛), chickens, and ducks. Since they keep cows, chickens, and ducks, the smell [of these animals] is extremely [unbearable]. ${ }^{45}$

43 Kawaji, Nagasaki nikki, p. 71.

44 Kubota, Nagasaki nikki, p. 101.

45 lbid., p. 103.
Kubota did not see these animals being slaughtered. Instead, he was entertained by the Russians with a banquet, which began with drinks and moved on to main dishes featuring meat. Although he detected animal fat and sweetness and sourness in every dish, he did not show any negative impression towards the smell. ${ }^{46}$ In short, Kubota's olfactory senses were offended only by the smell of live animals.

A retainer from Nagaoka domain (modern-day Niigata Prefecture), Kawai Tsugunosuke 河井継之 助 (1827-1868), had the opportunity to visit the Chinese quarter in 1859 at a time when the landscape of Nagasaki was in rapid transition. In 1856, the bakufu lifted the restrictions on Japanese and Dutch travel between mainland Nagasaki and Dejima. Then, upon the opening of Nagasaki to the United States, Russia, England, France, and Holland, the bakufu also abolished the Chinese quarter in 1859 and allowed the installation of the Dutch consulate within the headquarters of the Dutch East Company in 1860. So, when Kawai arrived at Nagasaki in October, there was an increasing number of foreigners visible on the street. While seeing shops owned by Westerners and Chinese people, he contrasted "the unruliness" of the Westerners to "the calmness" of the Chinese people. ${ }^{47}$ In addition, due to the Second Opium War (1856-1860), he found Westerners accompanying the Chinese people. When offered opium by the Chinese, he felt its smell to be "savory and nice," although he did not actually smoke..$^{48}$

The result of the Opium War was reported to the bakufu through Chinese and Dutch merchants, and the Japanese authorities were not only shocked by the Chinese defeat but also alerted to the possibility that Japan could also face a Western military threat in the near future. The fragrance of "noble and gentle" Chinese remarked on by the author of Nagasaki miyage above seems to reflect China's status as Japan's “most significant Other" in the ancient and medieval periods. ${ }^{49}$ Curiously, the smell of opium that had led such a significant "other" to catastrophic defeat does not carry a negative connotation but evoked a pleasantly foreign scent.

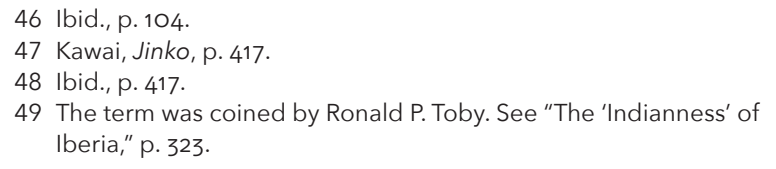




\section{Conclusion: Odorphobia of the "Foreign"}

Herz writes that people "learn the meaning (the connotation) of odors by association." That is, smell is contextual and "the olfactory system is set up so that, through experience, meaning becomes attached to odor stimuli." ${ }^{50}$ In this sense, the travelers to Nagasaki, whose actual perception of foreigners and meat we have examined, contextualized their experiences there with the knowledge they had acquired about these two "others," which contributed to the construction of a "Japanese" identity. They may have been taught what Amano referred to as "odorphobia" caused by the stench of meat. Or, they may have embraced the fear of being imbued with the stench of animal flesh. Here, the important point is that the "foreign" and "marginal" constituted the borders by which "Japan" was framed while those who felt disgust towards the smell of meat unconsciously mobilized their "national" identity to thwart the entrance of foreign practices into their everyday lives. They could cover their eyes and not look at animal flesh; they could refuse to eat meat dishes. But they could not avoid bad smells even by plugging their noses.

\section{Reference List}

Amano Sadakage 天野信景. Shiojiri 塩尻. Nihon zuihitsu taisei dai-3 ki 日本随筆体成第三期. Vols. 14, 15, and 17. Yoshikawa Kōbunkan, 1977-1978.

Ashton, Rosemary. One Hot Summer: Dickens, Darwin, Disraeli, and the Great Stink of 1858. Yale University Press, 2017.

Barnes, David S. The Great Stink of Paris and the NineteenthCentury Struggle against Filth and Germs. Johns Hopkins University Press, 2018.

Cohen, William A., and Ryan Johnson, ed. Filth: Dirt, Disgust, and Modern Life. University of Minnesota Press, 2004.

Corbin, Alain. The Foul and the Fragrant: Odor and the French Social Imagination. Harvard University Press, 1986.

Corbin, Alain. Village Bells: The Culture of the Senses in the Nineteenth-Century French Countryside. Columbia University Press, 1998.

50 Herz, "I Know What I Like," p. 194.
Cwiertka, Katarzyna J. Modern Japanese Cuisine: Food, Power, and National Identity. University of Chicago Press, 2006.

Fróis, Luis. Kuroda Kanbei no kaishū to shōnen shisetsu no kikoku 黒田官兵衛の改宗と少年使節の帰国. Trans. Matsuda Kiichi 松田毅一 and Kawasaki Momota 川崎桃 太. Chūō Kōronsha, 2000.

Furukawa Koshōken 古川古松軒. Saiyū zakki 西遊雑記. In Nihon shomin seikatsu shiryō shūsei 日本庶民生活史料 集成, vol. 2, pp. 329-95. San’ichi Shobō, 1969.

Hanley, Susan. Everyday Things in Premodern Japan: The Hidden Legacy of Material Culture. University of California Press, 1999.

Harada Nobuo 原田信男. Edo no ryōri shi: Ryōribon to ryōri bunka 江戸の料理史:料理本と料理文化. Chūō Kōronsha, 1989.

Harada Nobuo. Edo no shoku seikatsu 江戸の食生活. Iwanami Shoten, 2003.

Harada Nobuo. Rekishi no naka no kome to niku: Shokumotsu to tennōsei 歴史の中の米と肉: 食物と天皇 制. Heibonsha, 2005.

Hatano Shinsaku 波多野新作. Nagasaki dōchūki 長崎道中 記. Zama-shi Toshokan Shishi Hensan-gakari, 1988.

Hayashi Hideari 林英存. Tsukushi no michikusa 筑紫道草. In Sōsho Edo bunko 叢書江戸文庫, vol. 17, pp. 271-376. Kokusho Kankōkai, 1991.

Herz, Rachel S. "I Know What I Like: Understanding Odor Preferences." In The Smell Culture Reader, ed. Jim Drobnick, pp. 190-205. New York: Berg Publishers.

Hikone-shi 彦根市, ed. Shinshü Hikone shishi 新修彦根市 史. Vol. 7, Kinsei 近世 1. Hikone Shiyakusho, 2002.

Howell, David Luke. Geographies of Identity in NineteenthCentury Japan. University of California Press, 2005.

Kawai Tsugunosuke 河井継之助. Jinko 塵菛. In Nihon shomin seikatsu shiryō shüsei, vol. 2, pp. 397-440. San'ichi Shobō, 1969.

Kawaji Toshiakira 川路聖謨. Nagasaki nikki 長崎日記. Heibonsha, 1968.

Kubota Shigetsugu 窪田茂逐. Nagasaki nikki 長崎日記. Yonezawa-shi Shiryō Hensan Iinkai, 1984.

Manalansan IV, Martin F. "Immigrant Lives and the Politics of Olfaction in the Global City." In The Smell Culture Reader, ed. Jim Drobnick, pp. 41-52. New York: Berg Publishers, 2006.

Moeran, Brian. "Making Scents of Smell: Manufacturing and Consuming Incense in Japan." Human Organization 68:4 (2009), pp. 439-50.

Nagakubo Sekisui 長久保赤水. Nagasaki kōeki nikki 長崎行 役日記. Ibaragi: Tsukuba Shoin, 1994. 
Nagasaki miyage 長崎土産. In Nagasaki bunken sōsho dai-2 $s h \bar{u}$ 長崎文献叢書第二集, vol. 2, pp. 1-145. Nagasaki: Nagasaki Bunkensha, 1976.

O'Brien, Suzanne G. "Splitting Hairs: History and the Politics of Daily Life in Nineteenth-Century Japan." Journal of Asian Studies 67:4 (2008), pp. 1309-39.

Porter, Roy. "Foreward." In The Foul and the Fragrant: Odor and the French Social Imagination, ed. Alain Corbin, pp. v-vii. Harvard University Press, 1986.

Reinarz, Jonathan. Past Scents: Historical Perspective of Smell. University of Illinois Press, 2014.

Screech, Timon. The Lens within the Heart: The Western Scientific Gaze and Popular Imagery in Later Edo Japan. University of Hawai'i Press, 2002.

Shimizu, Akira. "Meat-Eating in the Kōjimachi District of Edo." In Japanese Food Ways, Past and Present, ed. Stephanie Assmann and Eric C. Rath, pp. 92-107. University of Illinois Press, 2010.

Smith, Mark M. How Race Is Made: Slavery, Segregation, and the Senses. The University of North Carolina Press, 2008.

Tachibana Nankei 橘南箕. Saiy ūki 西遊記. In vol. 98 of Shin Nihon koten bungaku taikei 新日本古典文学大系, pp. 174-390. Iwanami Shoten, 1991.

Takayanagi Shinzō 高柳真三 and Ryōsuke Ishii 石井良 介. Ofuregaki Hōreki shūsei 御触書宝暦集成. Iwanami Shoten, 1958.

Tanabe Tsukasa 田辺爵. “Furoku: 'Shiojiri' arekore” 付録 『塩尻』あれこれ (Amano Sadakage 天野信景, Shiojiri 塩尻). In vol. 13 of Nihon zuihitsu taikei dai-3 ki, pp. 1-2. Yoshikawa Kōbunkan, 1977.

Terajima Ryōan 寺島良安. Wakan sansai zue 和漢三才図 会. Vol. 1. Nihon shomin seikatsu shiryō shūsei 日本庶民 生活史料集成. Vol. 28. San’ichi Shobō, 1980.

Toby, Ronald P. “'Ketōjin' no tōjō o megutte”「毛唐人」の 登場をめぐって. In Kyōkai no connect Nihonshi 境界の日 本史, ed. Murai Shōsuke 村井章介, Satō Shin 佐藤信, and Yoshida Nobuyuki 吉田伸之, pp. 254-91. Yamakawa Shuppansha, 1997.

Toby, Ronald P. “The 'Indianness' of Iberia and Changing Japanese Iconographies of Other." Implicit Understandings: Observing, Reporting, and Reflecting on the Encounters between Europeans and Other Peoples in the Early Modern Era, ed. Stuart B. Schwartz, pp. 323-51. Cambridge University Press, 1994.

Toby, Ronald P. "Utamaro no ekizochikku to erochikku" 歌麿のエキゾチックとエロチック. In Utamaro 歌麿, ed. Yoshida Nobuyuki 吉田伸之 and Asano Shūgō 浅野秀 剛, pp. 47-81. Asahi Shinbun Shuppan, 1998.
Tōyama Kagemichi 遠山景晋. Zoku mizouki 続未曾有記. In Sōsho Edo bunko 叢書江戸文庫, vol. 17, pp. 171-270. Kokusho Kankōkai, 1991.

Tsukamoto Manabu 塚本学. Shōrui o meguru seiji: Genroku no fökuroa 生類をめぐる政治: 元禄のフォークロア. Heibonsha, 1983.

Uchiyama, Junzō. "San'ei-chō and Meat-Eating in Buddhist Edo." Japanese Journal of Religious Studies 19:2/3 (1992), pp. 299-303.

Vaporis, Constantine N. "Digging for Edo: Archaeology and Japan's Premodern Urban Past.” Monumenta Nipponica 53:1 (Spring 1998), pp. 73-104.

Yoshida Shigefusa 吉田重房. Tsukushi kikō 筑紫紀行. In Nihon kikōbun shūsei 日本紀行文集成, vol. 1, pp. 585-720. Nihon Tosho Sentā, 1979. 